International Journal of

Supply Chain and Logistics

(IJSCL)

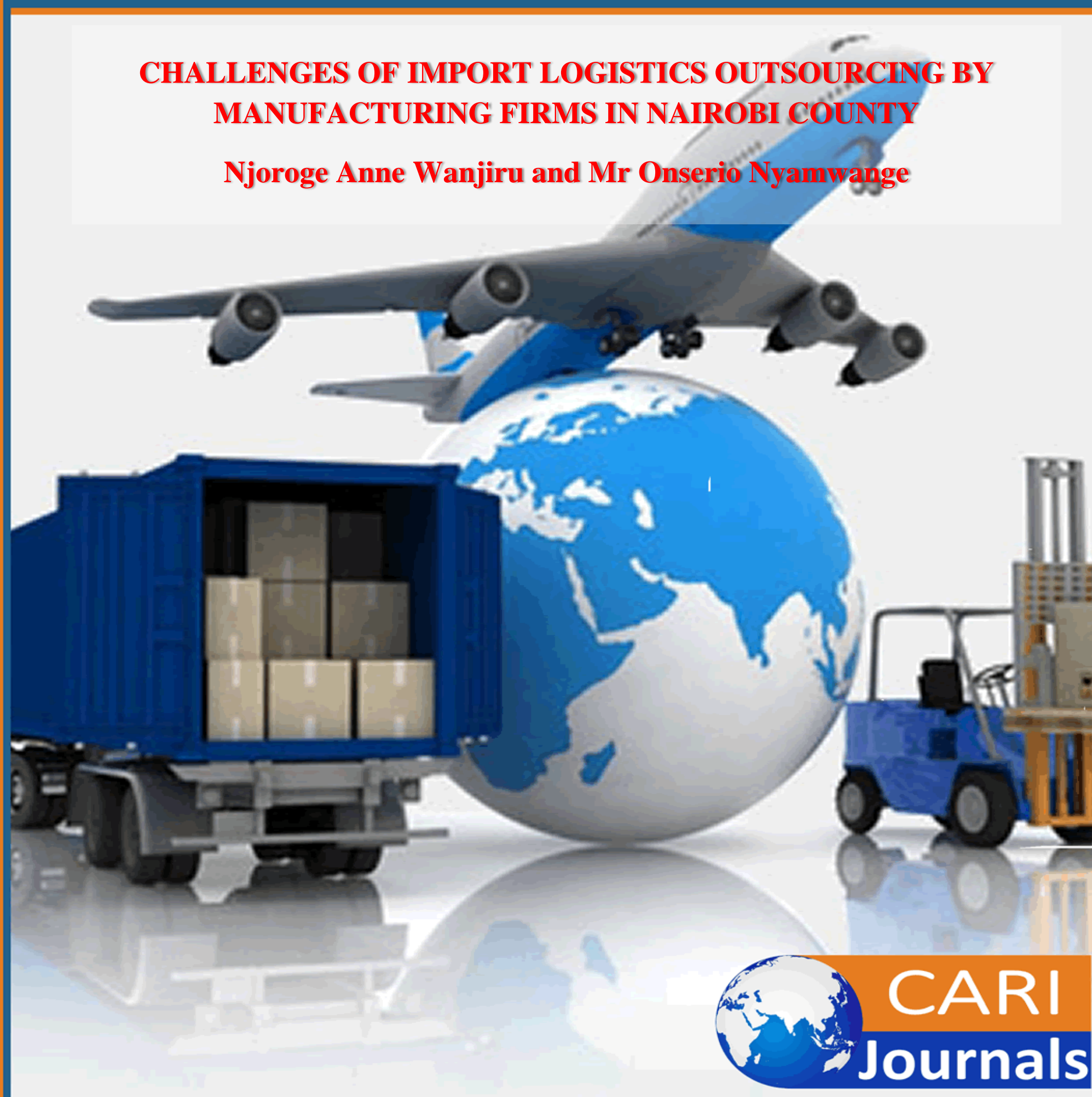




\title{
CHALLENGES OF IMPORT LOGISTICS OUTSOURCING BY MANUFACTURING FIRMS IN NAIROBI COUNTY
}

\author{
${ }^{1 *}$ Njoroge Anne Wanjiru \\ ${ }^{1 *}$ Postgraduate student: University of Nairobi \\ *Corresponding Author's Email: wnjoroge83@gmail.com
}

${ }^{2}$ Mr. Onserio Nyamwange

Lecturer: University of Nairobi

\begin{abstract}
Purpose: The purpose of this study was to investigate challenges of import logistics outsourcing by manufacturing firms in Nairobi County

Methodology: The research design of this study was a sample survey of the importers in the manufacturing industry as per the Kenya Association of Manufacturers. The total population of the companies in the manufacturing industry in Nairobi was 455 manufacturing firms. Primary data was collected via self-administered questionnaires with both open ended and closed questions that were designed to elicit specific responses for qualitative and quantitative analysis respectively. The data was analyzed by use of descriptive statistics.

Results: The results indicated that the important reasons of outsourcing were satisfactory in explaining the decision by manufacturing companies to outsource. The reasons of outsourcing are a key determinant in deciding to outsource import logistics. The extent of challenges the importers face when importing services also determined the decision to outsource in the firms.

Unique contribution to theory, practice and policy: The study recommends that the manufacturing firms should put more focus on core business functions and ensure reduction of overhead costs. They should take advantage of external expertise and experience and put measures to improve internal capabilities and expertise. The firms should reduce the total overall costs and where third party logistics providers provide a better service contract them. They should also emphasize on improved customer focus put measures to enable them compete effectively in the market.
\end{abstract}

Keywords: challenges, import logistics, outsourcing, manufacturing firms

\subsection{INTRODUCTION}

Outsourcing is in great demand in most companies due to the tremendous structural changes that have resulted to shrinking budgets, shrinking in house staff and downsizing. The option to transfer all or part of a company's business function to an external entity plays an increasingly important role in the strategic alignment of organizations (Kakabadse, 2003). Competitive pressures have forced companies to look objectively and critically at business processes. Companies have been outsourcing manufacturing operations, business services and even entire business lines for a long time now (Graf \& Mudambi, 2005). 
Many firms are using outsourcing as a strategic choice to improve company's competitive position and in achieving business objectives through reduced costs, increased revenues and profits. It has also emerged that companies that have used outsourcing makes gains in markets that would otherwise be uneconomical (Price Water House coopers, 1999). As companies seek to enhance their competitive positions in an increasingly global marketplace, they are discovering that they can cut costs and maintain quality by relying more on outside service providers for activities viewed as supplementary to their core business (Sinderman, 1995). Bender (1999) argues that the world has embraced outsourcing and that companies have adopted its principles to help them expand into other markets.

Logistics outsourcing provides certain power that is not available within an organization's internal departments. This power may have many dimensions such as; economic of scale, process expertise, access to capital and access to expensive technology (Babu, 2005). 3PL emerged in the early 1990's when logistics service providers started offering consolidated services and an increasing number of customers for a variety of reasons entered into longer business contracts with logistics service providers (Madhu, 1994). The global imperative for outsourcing accelerates as firms evolve from sellers of products and services abroad to setting up operations in foreign countries and staffing those operations with host countries or third party nationals (Greer et al., 1999).

Panayides et al. (2007) emphasized that, logistics is a functional system which is crucial for improving efficiency, both in the flow of goods and information and to meet low-cost, fast, and reliable delivery objectives within a company and throughout a network of companies. Logistics significantly contributes to company's competitive advantage in both efficiency and effectiveness. Logistics activities and processes are fundamental elements that a company's supply chain capabilities and competences are based upon. The close relationship between logistics and customer service, and its effect on a firm's competitiveness dictate that companies handle their logistics function prudently so as to achieve its full potential as a source of competitive advantage (Dzogbewu, 2010).

Many tasks associated with the logistics function as well as the entire function itself have been heavily outsourced. The tasks typically outsourced include freight auditing, leasing, maintenance and repair, freight brokering and consulting and training (Leenders et al., 2002). In logistics outsourcing the firm leverages on 3PLs expertise to perform its non-core activities and focusing more on core ones to achieve competitive advantage (Goolsby \&Whitlow, 2004). The council of Logistics Management defines a 3PL as a firm which provides multiple logistics services for use by customers. These services are integrated or bundled together by the providers which include transportation, warehousing, cross-docking, inventory management, packaging and freight forwarding. 3PL emerged in the early 1990s when logistics services providers started offering consolidated services and an increasing number of customers for a variety of reasons entered into longer business contracts with logistics service providers (Madhu et al., 1994).

In Kenya, the business environment has put a lot of pressure for firms to increase efficiency and productivity by cutting down costs and putting more emphasis on customer needs hence the need to outsource non-core business functions. This was brought about by globalization, liberalization and privatization concepts in global markets and economies (Ogachi, 2002). Importing is one of the leading businesses in Kenya. According to Kenya National Bureau of Statistics (KNBS) report (2012), Kenya imported more than double what it exported annually. Exports as a 
percentage of imports are 44.8\%, 43.8\%, 43.3\% and 38.8\% in the years 2008, 2009, 2010 and 2011 respectively (KNBS, 2012). Kenya is a net importer of capital goods such as petroleum products, machinery, vehicles, iron, steel and non-food supplies mainly from countries like China, India, South Africa, Japan, United States of America and United Arabs Emirates among others (CBK Report). According to the World Bank (2012), Kenya's imports accounted for $45.86 \%$ of the GDP in the year 2011.

Importation in Kenya has attracted many players both small and large enterprises who import both finished products and raw materials. Import duties account for largest share of revenue collected by the Government through KRA which is the collection agent. The custom services Department of KRA helps to regulate what the importers bring into the country to avoid illegal goods in the country. Importers outsource a number of services to 3PL's. These include: freight services, warehousing, transportation, clearing and forwarding. Most 3PL companies are not able to handle the all the functions that the importers would wish to be done thus they end up outsourcing to others e.g. a shipping agent has to use a shipping line to get the clients consignment from the country of origin to the country of destination either by sea or air for urgent cargo. Similarly, the clearing and forwarding agent may not have this own fleet of trucks for transportation of the goods from the ports to the premises of the clients (importers).

Kenya has a large manufacturing sector serving both the local market and exports to the East African region. The sector, which is dominated by subsidiaries of multi-national corporations, contributed approximately 13\% of the Gross Domestic Product (GDP) in 2004. According to Awino (2011), manufacturing is an important sector in Kenya and it makes a substantial contribution to the country's economic development. The industry is one of the key economic pillars in the vision 2030geared to make the nation a middle level income country by the year 2030. According to KAM, there are over 700established multi-sector manufacturing firms in Kenya where 455 are located in Nairobi. The firms differ in terms of products they produce and in size determined by the number of employees. The manufacturing industry has the potential to generate foreign exchange earnings through exports to diversify the country's economy and create employment.

\subsection{Statement of the Problem}

Customers are generally satisfied with the quality of services provided by 3PLs but there are always opportunities to improve service and relationships. According to Tech and Capgemini (2008), some of the customer challenges with 3PLs include service level not being realized, Information technology not sufficient and cost reduction not realized among others. According to Bardi and Tracey (1991); Bowman (1995); Byrne (1993); Cooke (1994b); Lynch et al. (1994) and Richardson (1993a), loss of control to the 3PL is one the greatest challenges. Byrne (1993) adds that the lack of advanced information technology linking manufacturer, carrier, warehouse, and customer operations has often caused hindrance to contract logistics management. According to Bradley (1995), the inability of the 3Pls to respond to the changing requirements and lack of understanding of the buyers' business goal difficulty of changing providers are potential problems by their users. Cooke (1994b) and Maltz (1995) assert that the third party may be inadequate in its capabilities to meet users' requirements in terms of service delivery.

Studies conducted in Kenya among them studies by Serem (2002), Mulama(2012) Barako \& Gatere (2008), Mugi (2011). Mugi (2011) found that most banks outsourced to achieve 
competitive advantages by outsourcing none core activities challenges which include information security and privacy issues, high transaction costs and other hidden costs. Mulama (2012) in his study on logistics outsourcing practices and performance of large manufacturing firms in Nairobi found that the most outsourced services by these firms are warehouse, transport and material handling management at $89.5 \%, 78.9 \%$ and $73.7 \%$ respectively. He also found out that outsourcing had an effect on the performance of the firms resulting to increased productivity, organizational effectiveness, and increased profits among others. The shortcoming in this study is that it looked at the outsourcing in general not specific functions. Serem (2002) in a survey of outsourcing human resource services(HRS) by banks in Nairobi found out that $61.22 \%$ of commercial banks outsource HRS and all the respondents cited benefits of reduced administrative costs and focus on core competence as the main drivers to outsourcing.

Barako and Gatere (2008) in their study on outsourcing practices of the banking industry found out that the most outsourced services by banks was ATM, card processing 58\% and internal audit $16 \%$ and the least outsourced service was customer account processing. The study further found out that $67 \%$ of the respondents cited cost reduction and focuses on core business as the benefit they derive from outsourcing. Gitaari conducted his study on professional membership based institutions all finding out that these firms outsourced to focus on core business and reduce overall costs. Chanzu (2002) in a study of all the manufacturing industries in Nairobi found that firms outsourced various activities and this was most prevalent in departments like human resources, finance and information technology. There was greater drive towards the use of outsourcing as a strategy to cut cost, pursue the core business activities and outsource the noncore activities.

A study by Agure (2006) found out that $87.9 \%$ of large flower firms outsourced human resource management services which were considered a strategic management tool. However, while the studies have shown tremendous benefits, there is also a dark side of outsourcing (Gitaari, 2011). According to Serem (2002), outsourcing can result in union grievances over job losses or changes hence posing a serious threat to the organization. All the studies stated above researched in outsourcing. However, none of the researchers addressed the challenges importers face by outsourcing their functions to 3Pls. This study therefore is being conducted to find out what these challenges are faced especially in relation to the use of freight services, clearing and forwarding agents,. It will seek to answer the following questions: What motivates importers to outsource the logistics services? What challenges do importers face when they outsource logistics services? What are the risks of outsourcing the services? How do they respond to the risks and challenges?

\subsection{Research Objectives}

i. To determine motivating factors in the outsourcing of import logistics services among manufacturing companies.

ii. To establish the challenges faced in the process of outsourcing import logistics services among manufacturing companies in Kenya.

\subsection{LITERATURE REVIEW}

\subsection{Logistics Outsourcing and Import Logistics Services}

The idea of outsourcing has its roots in the competitive advantage theory propagated by Adam smith (1776) in his book the wealth of nations in that a firm should specialize in products that its 
good at to achieve competitive advantage. Outsourcing concept spread over the 1980's and 1990's where firms emphasized more on core business functions and out sourcing non-core business functions. This was brought about by globalization, liberalization and privatization concepts in global markets and economies (Ogachi, 2002). Import movement usually involves more than just transportation. It involves clearing customs of the exporting country and entering the customs territory of the importing country. According to Donald et al. (1995), it involves production and presentation at the proper time and place of various import-export documents of entry, licenses, permits and various declarations incidental to the international trade in merchandise.

Outsourcing is the subcontracting of a company non- core function such as product design of manufacturing company to a third-party company. It is the activity that involved mainly two parties. The clients company who outsource logistics activities and the outsourcing service provider who performed the outsource activities. The decision to outsource is often made in the interest of lowering a firms cost and conserving energy directed towards the core functions of the firm, in order to make more efficient use of labor, capital, technology and resources (Vallespir et al., 2001, Quinn et al., 1994). In outsourcing the firm leverages on 3PLs expertise to perform its non-core activities and focusing more on core ones to achieve competitive advantage (Goolsby \& Whitlow, 2004).

According to the council of logistics management, 3Pl is a firm which provides multiple logistics services for use by customers preferably these services are integrated or bundled together. The services include transportation, warehousing, cross docking, inventory management, packaging and freight forwarding. According to Edward et al (2008), 4pl on other hand is a firm that assembles and manages the resources, capabilities and technology of its own organization with those of complementary service providers to deliver a comprehensive supply chain solution. 3PL emerged in the early 1990s when logistics services providers started offering consolidated services and an increasing number of customers for a variety of reasons entered into longer business contracts with logistics service providers (Madhu et al., 1994).

The functions performed by 3PLs ranges considerably. According to the 2001 survey conducted by Lieb and Schwarz (2001), 3PLs provide Fortune 500 manufacturers a wide variety of services and they provide the typical user with multiple logistics services. The most used logistics functions provided by 3PL in 2001 were: direct transportation services (61\%), warehouse management/operations (59\%), shipment consolidation services (49\%), freight forwarding (45\%), carrier selection (43\%), inventory replenishment (41\%), customs brokerage (41\%), and carrier performance measurement (41\%).

According to Harrison et al. (2002), the importance of outsourcing becomes particularly evident when companies look critically at their internal structure and resources. Outsourcing provides companies with greater capacity for flexibility especially in the purchase of rapidly developing new technologies. By outsourcing logistics activities, firms can save on capital investment, and thus reduce financial risks. Investment on logistics assets, such as physical distribution centers or information networks, usually needs large lump sum of money, which involved high financial risk. Outsourcing is a viable business strategy because turning non-core functions over to external suppliers enables companies to leverage their resources, spread risks, and concentrate on issues critical to survival and further growth. Many companies turned to outsource logistics 
activities as a way of restructuring their distribution networks and gain competitive advantage (Sink et al., 1997).

\subsection{Drivers of Outsourcing}

The reasons why a company decides to outsource can vary greatly. It allows firms to focus on their core business thus create competitive advantage while reducing costs .According to Lambert et al. (1999), outsourcing logistics activities has increasingly become an effective way to reduce costs and spread risks for traditional vertically integrated firms. The main reason why firms outsource their logistics activities to third-party logistics providers is to reduce costs (Mercer Management Consulting, 2002). Today, third-party logistics is a key component of logistics management strategy in many industries (Gooley, 2002).

Of the many factors that may act as driving forces behind outsourcing, globalization of business has been viewed by many Byrne (1993); Foster and Muller (1990); Rao et al. (1993); Sheffi (1990) and Trunick (1989) as the most prominent. One of the most important reasons for employing third-party logistics providers is their ability to provide their clients with expertise and experience that otherwise would be difficult to acquire, or costly to have in-house (Byrne, 1993; Dillon, 1989; Goldberg, 1990; Richardson, 1990, 1992, 1993a, \& 1993b; Sheehan, 1989; Trunick, 1989). Their expertise gained from working with other clients allows users to benchmark against other companies and may lead to opportunities to lower costs and improve customer service.

Trunick (1989) suggests emerging technology and versatility of third parties as two other important drivers of outsourcing. Since it would be time consuming and expensive to develop and implement new technologies in-house, firms can easily employ those of a third-party. On the other hand, versatility of the third parties enables them to provide an improvement in control, technology, and location, turning fixed costs into variable costs. Small companies tend to be more interested in third- party use (Maltz, 1994) since they are in greater need for expertise and assistance in the area of technology (Harrington, 1995b).

The most logical reason for using 3PL services is a lack of internal capabilities. Companies with little transportation and logistics expertise would be wise to outsource rather than attempting to build internal operations. For example Proctor \& Gamble and Walmart are companies with premier supply chain capabilities yet they make extensive use 3PL service providers to reduce costs, increase resource capacity, and fill gaps in expertise.

\subsection{Benefits of Outsourcing}

According to Lieb et al. (2004), across many industries, outsourcing logistics activities has become a rapidly expanding source of competitive advantage and logistics cost saving. He reported that some firms routinely have achieved $30-40 \%$ reduction in logistics costs and have been able to greatly streamlined global logistics processes as a consequence of outsourcing. Logistics significantly contributes to company's competitive advantage. Gitaari (2011) asserts that some of the benefits achieved by outsourcing included cost cutting, ability to focus on core business and new ideas that were acquired that helped improve service delivery because contracts were being renewed based on performance. Thompson and Strickland (2004) advanced the following merits of outsourcing: company being able to concentrate on its core business, access to skilled manpower at affordable prices, increased productivity and ability to access world class technology at lower rates. 
The most obvious reason behind outsourcing logistics activities is to provide very effective means of reducing costs by contracting with a third-party who can provide better services and high quality at a lower cost. By reducing costs through outsourcing, you gain the ability to improve operating efficiency, increase return on assets, and improve profitability. Outsourcing is also an effective means of generating new revenues. A firm which outsource can contract with a third-party to provide products and services which it cannot offer on a profitable basis . This form of outsourcing enables a client firm to test market demand for a services or product if it is less risky, more cost-effectively way than creating the service internally with scarce resources (Panayides et al., 2005).

Outsourcing offers many advantages to those using it. It reduces capital investment in facilities (Foster and Muller, 1990; Richardson, 1992; 1995), equipment (Fantasia, 1993; Foster \& Muller, 1990; Richardson, 1995), information technology (Fantasia, 1993; Goldberg, 1990; Lacity et al., 1995; Richardson, 1995; Sheffi, 1990; Tr unick, 1992) and manpower (Foster \& Muller, 1990; Richardson, 1992; 1995). This allows the using firm greater flexibility in adapting to changes in the market and access to leading edge technology (Lieb, 1992; Sheffi, 1990). Firms only need to contract for the necessary level of service to meet current demand and when demand surges beyond the capability of a firm to fulfill, a third-party may be called in to help the firm. Thus, the contract logisticians convert a fixed cost to a variable cost for users (Bradley, 1994b; 1994c; Richardson, 1993a).By coordinating production and shipping schedules, outsourcing reduces inventory and improves inventory turnover rate (Richardson, 1990; 1995) resulting in faster transit times, less damage, and less paper work. Contract logistics also enables firms to respond quickly to marketing, manufacturing, and distribution changes (Byrne, 1993) and helps to improve on-time delivery (Richardson, 1995).

Third-party logistics users generally agree that it costs less to use such firms than to carry out the same functions in-house (Candler, 1994; Lieb, 1992). Logistics being their core business, these firms can lower costs by being more efficient than a manufacturer (Bradley, 1994c; Lieb, 1992). Since the use of an outside multiple service provider reduces the needed multiple service contacts for the firm to a single point of contact (Richardson, 1990), coordination costs are also reduced. In a recent Purchasing Magazine survey, more than 50 percent of the participating contract logistics users cited cutting transportation/ distribution costs, freeing up or reducing staff, focusing on the core business and cutting internal administrative costs as major reasons for using third-party logistics. Other reasons cited included acquiring outside expertise, consolidating services, improving service to the company, improving customer service and satisfaction, simplifying the logistics process, avoiding capital expenditures, using provider's logistics information systems, increasing productivity and reducing number of service suppliers (Bradley, 1995a). This study reveals that reasons for outsourcing have not varied much over the years.

\subsection{Challenges and Risks of Outsourcing}

Outsourcing usually reduces a company's control over how certain services are delivered which in turn may raise the company's liability exposure (Guterl, 1996). According to Gitaari (2011), the challenged faced were vendors not providing quality services as agreed, decreased company loyalty and lack of confidentiality on company matters. Haizer and Render (2008) asserted that some of the drawbacks of outsourcing include loss of control, increase in transportation costs if the distance from the outsourcing provider to a client firm and creating future competition. For 
example Intel outsourced chip production to Advanced Micro Devices (AMD) when it could not cope with the early demand. Within a few years AMD became a leading competitor manufacturing its own chips. He also said that a company that outsources can get into problems if the service provider is unable to provide the services due to bankruptcy, lack of funds or labor. Organizations are at risk of becoming dependent on the outside suppliers of services, failing to realize the purported hidden cost savings to outsourcing, losing control over critical functions and having to face prospects of managing relationships that go wrong and lowering the morale of permanent employees (Currie \& Willcocks, 1997; Kliem, 1999).

The goal of any organization outsourcing its logistics activity is entirely different from that of the service provider. Due to these differences, the factors that determine the commercial merit of the partnership are being considerably different. Considerations of these factors are essential to ensure the viability of the collaborative venture and the future success of the partnership. Any firm that outsourced its logistics activities to a third-party logistics serviced provider runs the risk of becoming over dependent on the provider (Piachaud, 2002). Loss of control to third-party provider(s) appears to be the most commonly cited reservation that inhibits firms from using contract logistics (Bardi and Tracey, 1991; Bowman, 1995; Byrne, 1993; Cooke, 1994b; Lynch et al., 1994; Richardson, 1993a). Byrne (1993) adds that the lack of advanced information technology linking manufacturer, carrier, warehouse, and customer operations has often caused hindrance to contract logistics management.

Besides losing control, losing touch with important information, failure to select or manage providers properly, unreliable promises of the providers, their inability to respond to changing requirements, their lack of understanding of the buyer's business goals and difficulty of changing providers have also been cited as potential problems by their users (Bradley, 1995a). A major obstacle to outsourcing is the difficulty of obtaining organizational support (Bowman, 1995). Management's lack of confidence in an outside company to deliver service at as high a level as the company employees is a major issue: the third party may be inadequate in its capabilities to meet users' requirements (Cooke, 1994b; Maltz, 1995). Difficulty of assessing the savings to be gained through outsourcing creates additional problems. Also, the use of an outside firm may make the firm's logistics people apprehensive about their job- security: they may develop a fear of being retrenched (Cooke, 1988; Muller, 1991b). There exists an information asymmetry in logistics outsourcing. The third party logistics provider rarely has complete information about the contracting company; similarly the contracting company may have incomplete information about the third party logistics provider. For example, if a third party logistics provider has incomplete information about the contracting companies' cost structure, the price it will offer may not be well matched to that cost structure.

If a firm has outsourced its logistics services, its logistics innovative ability may be impaired (Earl, 1996). In the long run, if a firm wants to maintain its comprehensive competitive competences, it will have new ways of providing logistics services for the business. External sourcing does not guarantee innovation. During outsourcing contract periods, the third party logistics provider may not recognize an opportunity to innovate as its focus may be primarily on costs. According to a recent study of IT outsourcing by Bartholomew (2001), who examined hidden costs, benefits can be eroded by costs that firms' managers cannot identify a priori. Many firms underestimate the costs associated with selecting a third party logistics provider, negotiating and drafting a contract, additional time and expense early on helps avoid problems 
later, such as having to renegotiate the contract or constantly monitor the logistics provider to get the needed performance. Estimating transition costs can be very difficult. A firm that outsources its logistics activities to a third party logistics provider runs the risk of becoming dependent on that provider. By contracting out logistics activities to the same third party logistics provider over a long period of time, the firm may find itself in an increasingly vulnerable position and may even lose control of part of its logistics activities.

In outsourcing arrangements, partial control of a project inevitably passes from the sponsor to the collaborator. The extent to which the firm may effectively control an outsourced logistics business will be greatly determined by the information received and the early detection of problems. There is also the risk of conflicts in firms' culture brought about by the fact that the goals of each party are often different so the factors that determine the commercial merit of the partnership are being considered from different perspectives. Management styles and degrees of bureaucracy within firms may also be different. Consideration of these factors is essential to ensure the viability of the collaborative venture and the future success of the partnership (Piachaud, 2002).

\subsection{Mitigating Outsourcing Challenges}

One of the ways of mitigating challenges is use of performance assessment indices for both cost and service measures to evaluate systematically the performance of integrated third party logistics operation, reflect accurately the relationship between third party logistics providers and firms and realize effectively the integration of third party logistics providers and users. The most common risks and challenge in logistics outsourcing are probably decision making risk due to incomplete information and moral risks resulting from asymmetric information. In order to avoid potential problems, information sharing encouragement mechanisms must be developed. Information technologies can be used to establish these information sharing mechanisms which can lead to win-win situations for both participating parties.

In logistics outsourcing, key operational information such as costs, demands, shipment plans, capacities, etc., should be easily accessible by both participating parties. Such information should be accurate and timely, rendering it useful to both parties for planning and re-planning purposes. Thus, it is important that information sharing encouragement mechanisms are established so that any updates are made as timely as possible. It is important for a third party logistics provider to design a suitable third party logistics-performing tactic. Designing a suitable performance tactic, another valid measure to prevent performance risks, enables third party logistics providers to improve customer service levels and ensure that successful logistics partnership are developed.

There exists an information asymmetry in logistics outsourcing. The third party logistics provider rarely has complete information about the contracting company; similarly the contracting company may have incomplete information about the third party logistics provider. For example, if a third party logistics provider has incomplete information about the contracting companies' cost structure, the price it will offer may not be well matched to that cost structure. If a firm has outsourced its logistics services, its logistics innovative ability may be impaired (Earl, 1996). In the long run, if a firm wants to maintain its comprehensive competitive competences, it will have new ways of providing logistics services for the business. External sourcing does not guarantee innovation. During outsourcing contract periods, the third party logistics provider may not recognize an opportunity to innovate as its focus may be primarily on costs. 
In outsourcing arrangements, partial control of a project inevitably passes from the sponsor to the collaborator (Piachaud, 2002). The extent to which the firm may effectively control an outsourced logistics business will be greatly determined by the information received and the early detection of problems. There is also the risk of conflicts in firms' culture brought about by the fact that the goals of each party are often different so the factors that determine the commercial merit of the partnership are being considered from different perspectives. Management styles and degrees of bureaucracy within firms may also be different. Consideration of these factors is essential to ensure the viability of the collaborative venture and the future success of the partnership (Piachaud, 2002).

\subsection{Empirical Studies in Outsourcing Practices}

Since the early 1990s, the worldwide practices of outsourcing logistic activities have been increasing, resulting in an annual 10\% increase (Sohail et al., 2003). According to "Cap Gemini Ernst \& Young" survey (2002), the rates of resorting to logistic suppliers have reached 94\% in Europe, 78\% in North America and 92\% in Pacific Asia. Gitaari (2011) conducted a study at KIM with cost reduction and focus to core business as the main drive towards outsourcing and that it played a big role in achieving business objectives. Serem (2002) in a survey of outsourcing human resource services(HRS) by banks in Nairobi found out that $61.22 \%$ of commercial banks outsource HRS and all the respondents cited benefits of reduced administrative costs and focus on core competence as the main drivers to outsourcing. Barako and Gatere (2008) in their study on outsourcing practices of the banking industry found out that the most outsourced services by banks was ATM, card processing 58\% and internal audit 16\% and the least outsourced service was customer account processing. The study further found out that $67 \%$ of the respondents cited cost reduction and focuses on core business as the benefit they derive from outsourcing.

\subsection{RESEARCH METHODOLOGY}

The research design of this study was a sample survey of the importers in the manufacturing industry as per the Kenya Association of Manufacturers (KAM) 2013. The total population of the companies in the manufacturing industry in Nairobi was 455 (KAM 2013). Due to their high numbers, the researcher sampled them according to the 12 sectors they operate in as defined by KAM. Stratified random sampling method was applied in coming up with the sample size. Primary data was collected via self-administered questionnaires with both open ended and closed questions that were designed to elicit specific responses for qualitative and quantitative analysis respectively. The data was analyzed by use of descriptive statistics.

\subsection{RESULTS AND DISCUSSIONS}

A total of 46 questionnaires were issued out and 39 were returned giving a response rate of $85 \%$.

\subsection{Organizational Data}

The organizational data considered in this study was the number of years the company has been in existence and the ownership details. The study sought to establish the duration of manufacturing company's existence. Above seventy percent (76.9\%) had been existence for over 16 years while $18 \%$ had been in existence for 11 to 15 years. About five percent $(5.1 \%)$ had been 
in existence for 6 to ten years. These findings imply that majority of the companies had been in existence for an extensive duration and hence constituted of a good population sample for the study.

The study also sought to find out the ownership details of the companies whether owned locally, foreign or both locally and foreign. Majority of the companies (43.6\%) were owned by both locals and foreigners, while $33.3 \%$ percent of the respondents were owned locally. Above twenty three percent (23.1) are owned by foreign investors. These findings imply that the manufacturing industry attracts both local and foreign investors on a bigger margin compared to either local investors or foreign investors.

\subsection{Reasons for Outsourcing}

The study sought to establish Extent to which the companies outsourced their services. The findings were presented in Table 1. Freight services were fully outsourced with a mean of 5.0. Brokerage services, clearing and forwarding services and brokerage services were adequately outsourced with a mean of 4.9, 4.3 and 4.2 respectively. Shipment planning services were moderately outsourced with a mean of 3.3. Warehousing was lowly outsourced with a mean of 2.8. The overall mean was 4.07 with a standard deviation of 0.86 . These findings imply that most manufacturing companies outsourced most of their services rather than performing them internally. This can be explained by the fact that acquiring the equipment required for such services freight services is expensive.

Table 1: Extent of Outsourcing

\begin{tabular}{lcc}
\hline Statement & Mean & Std. Deviation \\
\hline Fully outsourced & & \\
Freight services & 5.0 & 0.0 \\
Adequately outsourced & & \\
Clearing and forwarding & 4.9 & 0.3 \\
Brokerage services & 4.3 & 1.2 \\
Transportation & 4.2 & 0.9 \\
Moderately outsourced & & \\
Shipment planning & 3.3 & 1.0 \\
Lowly outsourced & & \\
warehousing & 2.8 & 1.8 \\
Average & $\mathbf{4 . 0 7}$ & $\mathbf{0 . 8 6}$ \\
\hline
\end{tabular}

The study also sought to find out if the services outsourced can be performed in-house. Sixty seven percent of the respondents felt that some of the services outsourced could be performed inhouse. These services that need not be outsourced included transportation, customs brokerage services, clearing and forwarding. Thirty three percent of the respondents on the other hand felt that none of those services could be performed within the company because of the costs involved in terms of infrastructure, licenses and the skills required. 
The study sought to establish to what extent the companies consider drivers of outsourcing in making the decision to outsource. The findings were presented in Table 2. Focuses on core business, operational flexibility, reduction of overall cost and efficient utilization of resources were adequately considered with means of 4.8, 4.5, 4.3 and 4.1 respectively. Lack of internal expertise was moderately considered with a mean of 3.5. The overall mean was 4.2 with a standard deviation of 0.8 . These findings imply that the drivers of outsourcing were highly considered by most manufacturing companies in making the decision to outsource.

Table 2: Drivers for Outsourcing

\begin{tabular}{lcc}
\hline Statement & Mean & Std. Deviation \\
\hline Adequately Considered & & \\
Focus on core business & 4.8 & 0.4 \\
Efficient utilization of resources & 4.5 & 0.7 \\
Reduce overall cost & 4.3 & 0.9 \\
Operational flexibility & 4.1 & 1.1 \\
Moderately Considered & & \\
Lack of internal expertise & 3.5 & 0.9 \\
Average & $\mathbf{4 . 2}$ & $\mathbf{0 . 8}$ \\
\hline
\end{tabular}

The study sought to find out whether the companies outsource all the services from one third party service provider. Ninety percent of the respondents said they do not. Ten percent of the respondents said that they outsource to one service provider for ease of management and follow up activities. These results imply that most of the companies do it in that the providers were a one-stop shop for all the services as most providers specialize in a specific area where they have competitive advantage.

The study sought to establish the importance of reasons for outsourcing. The findings were presented in Table 3.The most important reasons were; to focus on core business functions, improved overall organizational efficiency, to reduce investments required for infrastructure, IT enables access of materials only available abroad, to reduce overhead costs, to take advantage of external expertise and experience, to free up management time to carry out other functions, to enable use of resources not available internally and the ability to compete effectively in the market. The reasons had means of 4.7, 4.5, 4.5, 4.4, 4.3, 4.3, 4.3 and 4.2 respectively. Gain from economies of scale from the providers, the centralized facilities provided, to free up internal resources, the number of outsourced services being few, improved customer focus, IT enables the use of resources that are not available internally, third party logistics providers providing a better service, increased flexibility, reduction of concern with legal compliance issues, gaining more cost transparency, lack of internal capabilities and expertise, gaining access to IT resources unavailable internally and reducing the total overall costs were considered important reasons with means of $3.9,3.9,3.8,3.7,3.7,3.7,3.6,3.4,3.4,3.4,3.3,3.1$ and 3.0 respectively. The overall mean was 3.89 with a standard deviation of 0.82 . These results imply that the importance of the reasons for outsourcing are a big determinant of outsourcing decisions by manufacturing companies. These findings agree with those of Byrne (1993); Dillon (1989); Goldberg (1990); Richardson (1990, 1992, 1993a, \& 1993b), Sheehan (1989) and Trunick (1989) who found that one of the most important reasons for employing third-party logistics providers is their ability to 
provide their clients with expertise and experience that otherwise would be difficult to acquire, or costly to have in-house. The findings also agree with those of Candler, (1994); Lieb, (1992) who found that third-party logistics users generally agree that it costs less to use such firms than to carry out the same functions in-house. Logistics being their core business, these firms can lower costs by being more efficient than a manufacturer (Bradley, 1994c; Lieb, 1992).

Table 3: Reasons for Outsourcing

Mean Std. Deviation

\section{Statement}

\section{Most important}

To focus on core business functions

Improved overall organizational efficiency

Reduce investments required for infrastructure

It enables access of materials only available abroad.

To reduce overhead costs

Take advantage of external expertise and experience

Free up management time to carry out other functions

Ability to compete effectively in the market

Enable use of resources not available internally

\section{Important}

Gain from economies of scale from the providers

Centralized facilities provided

Free up internal resources

Reducing the total overall costs

Improved customer focus

It enables the use of resources that are not available internally

The third party logistics providers provide a better service

Increased flexibility

Reduce concern with legal compliance issues

Gain more cost transparency

Lack of internal capabilities and expertise

Number of outsourced services are few
Gain access to IT resources unavailable internally

0.5

4.5

4.5

4.4

4.3

4.3

4.3

4.3

4.2
0.7

0.8

0.8 
International Journal of Supply Chain and Logistics ISSN 2520-3983 (Online)

Vol.1, Issue No.1, pp 86 - 106, 2017

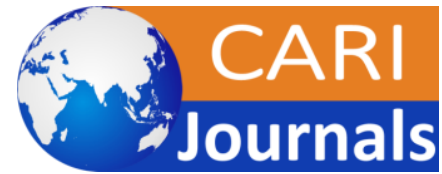

WWW.carijournals.org

\subsection{Challenges faced and Mitigation Measures Used}

The study sought to find out the challenges the manufacturing importers face when they outsource the import logistics services.

The study sought to establish how often 3PLs communicate to the manufacturing companies. Sixty percent of the respondents said that the 3PL's communicate extremely regularly, while $30 \%$ said they were very regular. Ten percent of the respondents said the 3PLs were seldom regular. The findings imply that the providers are able to give progress of any work assigned to them without any difficulties so that where the company needs to intervene the same is done. The main methods of communication as told by the respondents are phone calls and emails especially where a document needs to be sent by either party.

The study also sought to find out the quality of services rendered by the 3PLs. Fifty nine percent of the respondents believe that the performance of the logistics providers is average while 31 percent of the respondents thought that the 3PLs' quality of services is very good. Ten percent of the respondents rated the quality of service rendered as excellent. None of the respondents rated the services to be poor. These findings imply that most of the manufacturing companies have to bear with an average standard of quality in that the 3PLs also outsource some of their services to other providers.

The study sought to establish the challenges which importers face when outsourcing the logistics import services. The findings were presented in Table 4. Qualified and reliable suppliers, hidden costs, overreliance and disruption of supplies had big challenge with means of 4.4, 4.2, 4.1 and 4.1 respectively. Transaction costs, confidentiality and loss of control posed moderate challenge with means of 3.4, 3.3 and 3.3 respectively. Organizational learning, security problems, outsourcing partners, limited flexibility, loss of command, quality of work, employee loyalty, motivation loss and rate of innovation posed small challenge for manufacturing firms with means of 2.8, 2.6, 2.5, 2.4, 2.2, 2.1, 2.1, 2.1 and 2.1 respectively. Internal competence, low performance rates and the decision to outsource were not a challenge at all and had means of 1.9, 1.8 and 1.7 respectively. The overall mean was 2.79 with a standard deviation of 1.07 . These results imply that the extent of challenges had considerable effect on the decision by the manufacturing firms to outsource. These results agree with those of Currie and Willcocks (1997) who found that organizations are at risk of becoming dependent on the outside suppliers of services, failing to realize the purported hidden cost savings to outsourcing, losing control over critical functions and having to face prospects of managing relationships that go wrong and lowering the morale of permanent employees. Piachaud (2002) also found that the goal of any organization outsourcing its logistics activity is entirely different from that of the service provider. Due to these differences, the factors that determine the commercial merit of the partnership are being considerably different. Considerations of these factors are essential to ensure the viability of the collaborative venture and the future success of the partnership. Any firm that outsourced its logistics activities to a third-party logistics serviced provider runs the risk of becoming over dependent on the provider. 
International Journal of Supply Chain and Logistics

ISSN 2520-3983 (Online)

Vol.1, Issue No.1, pp 86 - 106, 2017

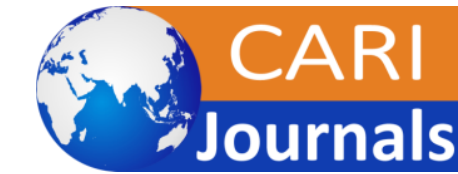

www.carijournals.org

Table 4: Extent of Challenges

\begin{tabular}{lcr}
\hline Statement & Mean & Std. Deviat \\
\hline Big challenge & & 1.0 \\
Qualified and reliable suppliers & 4.4 & 1.1 \\
Disruption of supplies & 4.2 & 0.6 \\
Overreliance & 4.1 & 1.2 \\
Hidden costs & 4.1 &
\end{tabular}

Moderate challenge

Transaction costs

1.1

Loss of control

1.2

Confidentiality

1.2

Small challenge

Organizational learning

1.2

Security problems

2.6

1.1

Outsourcing partners

2.5

1.1

Limited flexibility

0.8

Loss of command

2.2

1.0

Quality of work

2.1

1.2

Rate of innovation

2.1

0.9

Motivation loss

2.1

1.5

Employee loyalty

2.1

0.8

\section{Not a challenge}

Decision to outsource

Low performance rates

1.8

1.1

Internal competence

1.1

Average

The study sought to find out the measures manufacturing companies use to mitigate the challenges they face. The results are presented in Table 5. The findings indicate that $98 \%$ use insurance, $80 \%$ have partnerships with the service providers, $78 \%$ who do supplier score carding, $72 \%$ performing performance appraisal for the provider while $67 \%$ of the respondents have a department within the organization that performs some activities like clearing and forwarding. 
$97 \%$ and $92 \%$ said they do not have fully equipped departments to deal with outsourcing or a subsidiary company in outsourcing respectively because they would deviate from their core business while $89 \%$ indicated that they do not conduct any supply training and development to their service providers. Piachaud (2002) found that the extent to which the firm may effectively control an outsourced logistics business will be greatly determined by the information received and the early detection of problems. There is also the risk of conflicts in firms' culture brought about by the fact that the goals of each party are often different so the factors that determine the commercial merit of the partnership are being considered from different perspectives. Consideration of these factors is essential to ensure the viability of the collaborative venture and the future success of the partnership

Table 5: Measures taken to Mitigate Challenges

\begin{tabular}{lcc}
\hline Measure & Yes & No \\
\hline Partnership with service providers & 80 & 20 \\
Supplier score carding & 78 & 22 \\
Supplier developments and training & 11 & 89 \\
$\begin{array}{l}\text { Having a fully equipped department to deal } \\
\text { with outsourcing }\end{array}$ & 3 & 97 \\
$\begin{array}{l}\text { Having a subsidiary company that in the } \\
\text { business of outsourcing }\end{array}$ & 8 & 92 \\
$\begin{array}{l}\text { Performing part of the outsourcing activities } \\
\text { in-house e. g clearing and forwarding }\end{array}$ & 67 & 33 \\
$\begin{array}{l}\text { Performance appraisal for the service } \\
\text { providers }\end{array}$ & 72 & 28 \\
$\begin{array}{l}\text { Insurance } \\
\text { Average }\end{array}$ & 98 & 2 \\
\hline
\end{tabular}

\subsection{SUMMARY, CONCLUSION AND RECOMMENDATIONS}

\subsection{Summary}

The objectives of the study was to determine motivating the factors in the outsourcing of import logistics services among manufacturing companies and the challenges faced by these companies when they outsource import logistics services The study reviewed whether reasons for outsourcing, drivers of outsourcing, challenges of outsourcing and ways of mitigating these challenges were satisfactory in explaining the challenges of import logistics. The study revealed that the duration of most manufacturing companies' existence was over 16 years explained by $76 \%$ of the companies. Majority of the companies were owned by both local and foreign investors. The results generated through data analysis indicate that the importance of reasons of outsourcing were satisfactory in explaining the challenges. This was supported by an overall mean of 3.8. However the extent of the challenges the importers face when outsourcing the logistics import services was explained by an overall mean of 2.7.The measures taken to mitigate challenges had an overall mean of $52 \%$.

\subsection{Conclusions}

Based on the objectives and the findings from the results the following conclusions can be made. 
The reasons of outsourcing are a key determinant in deciding to outsource import logistics. The extent of challenges the importers face when importing services also determined the decision to outsource in the firms. These findings agree with those of Hendry, (1995) who found that companies should achieve those effects for which they have decided to outsource. So the effects of outsourcing are associated with the reasons for it. According to Lau and Hurley (1997), there is a significant relationship between outsourcing and profitability margin where they found that Chryslers profit margin is four times as high as that of GM due to effective outsourcing through strategic alliances. Frayer, Scannell, and Thomas (2000) suggest that companies are increasingly viewing outsourcing strategies as a means of reducing costs, increasing quality, and enhancing a firms overall competitive position.

\subsection{Recommendation}

Based on the objectives, the following recommendations were made; the manufacturing firms should put more focus on core business functions and ensure reduction of overhead costs. They should take advantage of external expertise and experience and put measures to improve internal capabilities and expertise. The firms should reduce the total overall costs and where third party logistics providers provide a better service contract them. They should also emphasize on improved customer focus put measures to enable them compete effectively in the market.

The firms should operate in such a way so as to minimize loss of control in decision making and limited flexibility as a way of mitigating challenge. They should work towards eliminating low quality work and put in place measures to curb leak of confidential information by third party logistics providers to competitors. They should minimize over reliance on the third party logistics providers and exercise selection of the right outsourcing partners. Manufacturing firms should work towards reducing high transaction costs and hidden costs. They should also put measures to address declining rate of innovation and enhance motivation loss of employees in regard to the outsourced services. They should also focus on minimizing loss of employee loyalty, potential security problems and disruption of supplies. They should identify qualified and reliable suppliers and clearly decide what to outsource and what not to outsource.

\subsection{Limitations}

The focus of the study was on large manufacturing companies who import raw materials in Nairobi hence did not cover other firms that import finished goods and even equipment. It was also limited in the region that it covered. The researcher also faced challenges in that some of the respondents were hard to reach due to their tight schedules while others were unwilling to cooperate due to organizational policies of information disclosure.

\subsection{Areas for further research}

This study confined itself to large manufacturing companies in Nairobi who outsource import logistics services. The findings may not be applicable to other companies that import finished goods and other small firms that import both finished goods and raw materials for manufacturing. It is therefore recommended that a study be conducted on the challenges faced by firms which import finished goods. 


\section{REFERENCES}

Barako, D. G., \& Gatere, P. K., (2008). Outsourcing practices of the Kenyan banking sector. African Journal of Accounting, Economics, Finance and Banking Research, 12(2).

Bardi, E. J., \& Tracey, M. (1991). Transportation outsourcing: a survey of US practices. International Journal of Physical Distribution \& Logistics Management, 21(3), 15-21.

Bendor-Samuel, P. (2000). Turning lead into gold: the demystification of outsourcing. Executive Excellence Publishers.

Bowman, R. J. (1995). A high-wire act. Distribution.

Bradley, P. (1995). Buying third-party services? Beware the bells and whistles. Traffic management, 24.

Byrne, P. M. (1993). A new road map for contract logistics. Transportation \& Distribution, April, pp. 58-62.

Candler, J. (1994). You make it, they distribute it. Nation's Business, 82(3), 46-48.

Cooke, J. A. (1994). Third-party logistics: Has its time come. Traffic management, 33(10), 7173.

Coopers, P. (1999). Global top decision makers' study on business process outsourcing. Price Waterhouse Cooper, Yankelovich Partners, and Goldstain Consulting Group, New York.

Dillon, T. F. (1989). Third-party services-new route to transportation savings. Purchasing World, 33(6), 32-33.

Dzogbewu, T. (2010). The outsourcing of logistical activities: The case of Guinness Ghana Breweries Limited.

Fantasia, J. J. (1993). Are you a candidate for third party logistics? Transportation \& Distribution, 34(1), 30. 
Foster, T. A., \& Muller, E. J. (1990). Third parties: your passport to profits. Distribution, 89(10), 30-32.

Gitaari D. M. (2011). Factors influencing outsourcing strategies at professional membership based institutions: a case of the Kenya institute of management (Doctoral dissertation, University of Nairobi).

Gold, T. (2004). Outsourcing software development offshore: Making it work. CRC Press.

Goldberg, D. (1990). JIT's next step: moves cargo and data. Transportation \& Distribution, 31(13), 26-29.

Gooley, T. B. (1994). How to meet the 'Big 8'logistics challenges. Traffic Management, November, 57-61.

Graf, M., \& Mudambi, S. M. (2005). The outsourcing of IT-enabled business processes: A conceptual model of the location decision. Journal of International management, 11(2), 253-268.

Greer, C. R., Youngblood, S. A., \& Gray, D. A. (1999). Human resource management outsourcing: The make or buy decision. The Academy of Management Executive, 13(3), 85-96.

Harrington, L. (1995). Small companies: find logistics tools. Transportation and Distribution, 36(3), 55-60.

Heizer J. \& Render B (2008). Principles of operations management. ( $7^{\text {th }}$ ed). International Journal of Physical Distribution \& Logistics Management, 21(3), 15-21.

Kakabadse, A., \& Kakabadse, N. (2003). Outsourcing best practice: transformational and transactional considerations. Knowledge and process management, 10(1), 60-71.

Lieb, R. C. (1992). The use of third-party logistics services by large American. Journal of Business Logistics, 13(2), 29. 
Lieb, R. C., \& Bentz, B. A. (2004). The use of third-party logistics services by large American manufacturers: The 2003 survey. Transportation Journal, 24-33.

Lynch, M. E., Imada, S. J., \& Bookbinder, J. H. (1994). The future of logistics in Canada: a Delphi-based forecast. Logistics and Transportation Review, 30(1), 95.

Maghanga, F. M. (2011). Logistics outsourcing practices among tea processing firms in Kericho County, Kenya (Doctoral dissertation, University of Nairobi).

Maltz, A. B. (1995). Why you outsource dictates how. Transportation \& Distribution, 36(3), 7380 .

Motari, F. M. (2015). Outsourcing of logistics: a survey of the practices of medium and large kenyan manufacturing firms (Doctoral dissertation).

Mugi, J. K. (2011). Business process outsourcing strategy and competitive advantage in commercial banks in Kenya (Doctoral dissertation, School of Business, University of Nairobi).

Mulama, O. (2012). Logistics outsourcing practices and performance of large manufacturing firms in Nairobi-Unpublished MBA project. University of Nairobi.

Ogachi, J. F. (2002). Strategic outsourcing: the experiences of companies listed in the Nairobi Stock Exchange (Doctoral dissertation, University of Nairobi).

Quinn, J. B., \& Hilmer, F. G. (1994). Strategic outsourcing. Sloan management review, 35(4), 43.

Richardson, H. L. (1992). Outsourcing: the power work source. Transportation \& Distribution, $33(7), 22-24$.

Serem, S. (2002). A survey of the outsourcing of human resource services by banks in Nairobi (Doctoral dissertation).

Sheehan, W. G. (1989). Contract warehousing: the evolution of an industry. Journal of Business Logistics, 10(1), 31. 
Sheffi, Y. (1990). Third party logistics: present and future prospects. Journal of Business Logistics, 11(2), 27.

Sinderman, M. (1995). Outsourcing gains speed in corporate world. National Real estate investor, 37(8), 42-50.

Sink, H. L., \& Langley Jr, C. J. (1997). A managerial framework for the acquisition of thirdparty logistics services. Journal of Business Logistics, 18(2), 163.

Sink, H. L., Langley Jr, C. J., \& Gibson, B. J. (1996). Buyer observations of the US third-party logistics market. International Journal of Physical Distribution \& Logistics Management, 26(3), 38-46.

Sohail, M. S., \& Sohal, A. S. (2003). The use of third party logistics services: A Malaysian perspective. Technovation, 23(5), 401-408.

Thompson, A. A., Strickland, A. J., \& gamble, J. J. (2006). Crafting and executing strategy. New Delhi Mcgraw hill.

Tr unick, P. A. (1989). Outsourcing: A single source for many talents. Transportation \& Distribution, July, pp. 20-23.

Tr unick, P. A. (1992). Carving a niche in global logistics. Transportation \& Distribution, February, pp. 57-8.

Vallespir, B., \& Kleinhans, S. (2001). Positioning a company in enterprise collaborations: vertical integration and make-or-buy decisions. Production Planning \& Control, 12(5), 478-487.

Watson, R., \& Pitt, L. (1989). Remarrying marketing and logistics with information systems technology. Industrial Management \& Data Systems, 89(1), 4-12. 